\title{
Why Do Judaism and Islam Prohibit Eating Pork and Consuming Blood? Part II: Medical and Demographical Consequences of Prohibition
}

\author{
Ilia Brondz \\ Norwegian Drug Control and Drug Discovery Institute (NDCDDI), Ski, Norway \\ Email: ilia.brondz@gmail.com
}

How to cite this paper: Brondz, I. (2020). Why Do Judaism and Islam Prohibit Eating Pork and Consuming Blood? Part II: Medical and Demographical Consequences of Prohibition. Voice of the Publisher, 6, 170182. https://doi.org/10.4236/vp.2020.64021

Received: November 4, 2020

Accepted: December 12, 2020

Published: December 15, 2020

Copyright $\odot 2020$ by author(s) and Scientific Research Publishing Inc. This work is licensed under the Creative Commons Attribution International License (CC BY 4.0).

http://creativecommons.org/licenses/by/4.0/

(c) (i) Open Access

\begin{abstract}
Historical, mythological, traditional, and some theological and hygienic aspects of the prohibition against consuming pork and blood were described in the 2018 paper by Brondz, "Why Judaism and Islam Prohibit Eating Pork and Consuming Blood as a Food?" (Voice of the Publisher, 4(2), 22-31,

https://doi.org/10.4236/vp.2018.42003). However, in that paper, the medical and demographic aspects influencing this issue were either not, or insufficiently, discussed. Some of the hygienic aspects are common to the breeding of other domestic animals, yet, whether consumption of their products has been prohibited has not been investigated. It is well known that the Armenian Orthodox Church prohibits eating hare, and in Hinduism, eating cattle or cattle products is prohibited. Herein, the goal is to shed light on the medical significance of the prohibition against pork consumption in Judaism and Islam, the possible demographical implications for Jews and Arabs, and some of the negative influences of this prohibition. Porcine hypodermic fat is white or yellow-white and has a relatively solid consistency. It also contains a significant amount of cholesterol. In humans, cholesterol is both partly synthesized de novo in the liver and partly absorbed by the small intestine from the food. Cholesterol plays an important physiologic role as a basis molecule for the partial resynthesis of many biologically active molecules that control fundamental functions within the endocrine, nerve, skeletomuscular, blood, and other systems.
\end{abstract}

\section{Keywords}

Judaism, Islam, Prohibition to Consume Pork, Medical and Demographical Consequences 


\section{Introduction}

Although Brondz (Brondz, 2018) described many aspects of the prohibition against pork consumption in Judaism and Islam, many other aspects were left unaddressed. The fundamental aspects of this prohibition were, and remain, morality and ethics. They represent the prohibition of cannibalism and consuming carrion and carrion eaters, as swine and carnivores often eat carrion. However, there is no modern explanation for why other religions prohibit the consumption of animals such as hare, in the Armenian Orthodox Church, or cattle, in Hinduism. In times of severe famine, some humans have resorted to cannibalism. The problem of overpopulation relative to agricultural food production has generally existed since the Neolithic age. For example, "The scarcity of resources has been a primary problem from the time of Neanderthal man to the present day. Neanderthals solved this problem by eating their new-born during famine..." (Brondz. \& Aslanova, 2019). Generally, "cannibalism has been practiced around the globe, up to modern times..." (Brondz \& Aslanova, 2019; List of Incidents of Cannibalism, https://en.wikipedia.org/wiki/List_of_incidents_of_cannibalism), (Stewart, 2017; Hjelmgaard, 2017). In Africa today, a significant portion of bush meat consists of monkeys and apes. The former dictator of Uganda, Idi Amin, often amused himself by eating human flesh. In fact, cannibalism exists among many species of insects, fish, and other animals (Fouilloux, Ringler, \& Rojas, 2019). In ancient times, the Middle Ages, and modern times, various techniques and ideologies have been used to achieve a balance between amount of population, food production and food consumption. In Australia, fertilization frequency was dramatically reduced by Aborigines, who "... solved this problem by penile manipulation, in which the phallus' urethra was sliced through from the testes to its opening" (Brondz. \& Aslanova, 2019). Food production and demography have always been interconnected and have always played a significant role in religiousand geopolitical decision-making.

\section{Demographical Meanings of Polyandry, Polygamy, and Monogamy}

Polyandry, in which a woman takes several husbands simultaneously, is practiced among Tibetans in Nepal and in parts of China and India. It is a custom characteristic of societies with scarce environmental resources where men engage in hard physical labor. In the Himalayas, polyandry is also connected to high altitudes with depleted oxygen supplies. Cumulatively, this results in fewer spermatozoa and poor male fecundity. Thus, the primary explanation for this custom is that it stabilizes the demography, maintaining a level above extinction. In Europe, this behavior is considered a perversity and occurs only in isolated cases. Polygamy has been evident since ancient times, documented in the Old Testament in pre-Judaic histories about Jakob, who had two wives and two concubines. From this developed the tradition that ordinary orthodox Jews have allowed up to four wives. The Old Testament describes the harem of King Solomon of Israel, who had up to 1000 wives and concubines. In Islamic tradition, 
polygamy was institutionalized and adopted as law. In some parts of Europe outside of the Roman Empire, polygamy existed and persisted until 1000 AD. By contrast, in ancient Rome and in Christianity, where strict monogamy was customary, serve as examples of social/sexual gender equality. However, following the Thirty Years' War (1618-1648), the population of what is now Germany fell from 16 to about 4 million; to correct this demographic situation, the Pope of Rome allowed men to marry young adolescent girls and encouraged priests to marry and raise families. A 1650 law gave men in northern Bavaria permission to have up to 10 wives simultaneously. At that time, polygamy was legal in parts of Europe, including Germany. Polyandry, polygamy, and monogamy are not universal or absolute religious laws; rather, they are used in times of socioeconomic need to balance a population's resources. Today, homosexual, and lesbian relations partly serve to reduce demographic pressures. Decades ago, Chairman Mao introduced the one-child policy to balance China's demography versus agricultural production. Some countries practice forced sterilization or abortion for the same reasons, particularly to reduce the minority's populations. The Old Testament describes the Pharaoh ordering the killing of all newborn Jewish males to reduce the Jewish population in ancient Egypt. Important to the thesis of this paper, nutritional implications of special foods, or the exclusion of some food ingredients, can also be used to influence individual's fecundity; however, if applied on a national level, it can also influence the demography. This aspect will be discussed later, including the positive and negative consequences of past, current, and future food prohibitions.

\section{Composition of Fats from Different Sources}

There are multiple examples of infectious diseases that can be transmitted between pigs and humans (Brondz, 2018). Pigs are a host animal for many coronaviruses, which can also be transmitted to pigs from other wild animals. However, the economic significance of pigs as a protein source for humans is evident. Along with swine flesh, humans also consume a substantial amount of fat. Most domestic's animal fat contains mono-, di-, and triglycerides, which, when digested by humans, this fat is converted to glycerol and fatty acids belonging to the class of saponifiable fats (Brondz, 2002, 2005, 2016), http://dx.doi.org/10.1016/B978-0-12-409547-2.13780-1.

Some vegetable oils contain phytosterols such as phytoestrogens, phytostanols, and phytoestrin. These are biologically active substances. Some of which have hormonal effects and, in vivo, can be transformed to hormones or substances with hormonal effects that are like estrogens or androgens. Prolonged ingestion of these fats can modify sexual ability, performance, and even fecundity. Swine white hypodermal fat has a different composition compared with fat from milk, fat from cattle, mutton, poultry, and fish. Most investigations have concentrated on the saponified portion of swine fat. Pork muscular flesh is lean, whereas its fatty layer is hypodermic fat tissue, which is usually white or yellow-white and 
relatively firm. Swine meat contains a relatively high cholesterol content, with 56 - 60 mg cholesterol per 100 gr of meat (Kasprzyk, Tyra, \& Babicz, 2015). Other authors have reported similar values of 98 - $95 \mathrm{mg} / 100 \mathrm{gr}$ (Bragagnolo \& Rodriguez-Amaya, 2002) and "cholesterol concentrations in fat and muscle tissues respectively ranged from 52 to $77 \mathrm{mg} / 100 \mathrm{gr}$ and from 55 to $65 \mathrm{mg} / 100 \mathrm{gr}$ ” (Maraschiello, Díaz, \& Regueiro, 1996). This concentration of high-fat cholesterol has a pronounced effect on humans.

\subsection{What Is Cholesterol?}

The chemical formula of cholesterol, which is a polycyclic alcohol with one unsaturated ring, is $\mathrm{C}_{27} \mathrm{H}_{46} \mathrm{O}$ (see the structural formula in Figure 1), its exact mass is 386.3549 . If molecules should be characterized by an organism's synthesis ability, then the human body contains three molecule types. The first type can be synthesized de novo from basic chemical elements. The second type can be synthesized partially de novo from basic chemical elements or using parts (i.e., blocks) of degraded molecules from the catabolic pool for the partial synthesis, or by using the products of digestion. The third type can neither be synthesized de novo nor can be synthesize from parts of degraded molecules from the catabolic pool for partial synthesis; these are essential molecules that must be ingested intact or as parts of complex substances. These are essential molecules. Cholesterol can also be endogenous or exogenous. In humans, cholesterol can be synthesized de novo, or the result of digestion from more complex substances, or absorbed directly as is from food, or reabsorbed from intestines. Cholesterol is not an essential molecule, so depriving an organism of exogenous sources this induces synthesis that sustains nearly normal levels. Introduction of excess of cholesterol can alter multiple processes. In some cases, this can have partly negative consequences, though it can also induce or suppress the production of other essential molecules or hormones. Prolonged ingestion of cholesterol-rich foods can influence an organism's cholesterol and metabolite balances. Hormonal and immune statuses can also be influenced.

\subsection{Cholesterol Excretion, Recycling, and Metabolism}

Both exogenous and endogenous cholesterol can be excreted from the digestive tract or reabsorbed in intestines. Cholesterol and many of its metabolites are

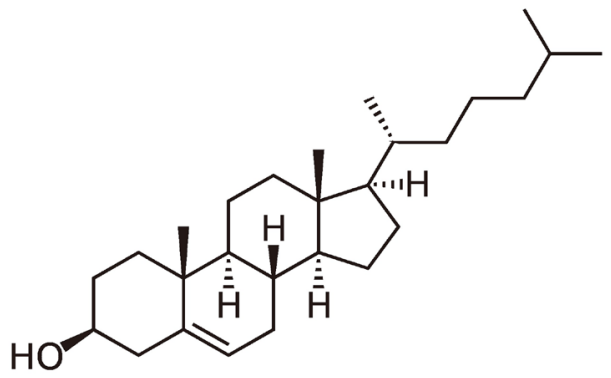

Figure 1. The molecule of cholesterol. 
mostly excreted with feces, though a small portion is excreted with sweat. Exogenous cholesterol is absorbed via the small intestine, while endogenous cholesterol is reabsorbed by the jejunum, both are absorbed in the presence of bile salts. Cholesterol is also recycled within the body. The liver excretes cholesterol or as its conjugated molecule into biliary fluids, which then excrete as a non-esterified or as a conjugated form into the digestive tract. Fifty percent of excreted cholesterol is reabsorbed by recycling. Cholesterol enters the cells of the intestinal mucosa and is incorporated into chylomicrons, which then enter the blood circulation via the lymphatic system, where they are transported to different organs through veins and arteries and/or transformed/metabolized into partially new molecules. Cholesterol easily forms oxygenated derivatives called oxysterols, which exert inhibitory actions on cholesterol biosynthesis and participate in bile acid biosynthesis and the regulation of gene transcription.

\subsubsection{Bile Acids}

Bile acids and salts are synthesized in the liver from oxidized cholesterol. Bile acids are conjugated with glycine, taurine, glucuronic acid, or sulphate; these conjugated and non-conjugated bile acids and cholesterol are then excreted into the bile bladder. These are the body's natural detergents, emulsifying fats in the gut during digestion. Without bile acids, the supply of fatty acids and fat-soluble substances as fat-soluble vitamins would be impossible. Bile acids, as detergents, play a major role in immune defense by assisting the lysis of microorganisms by lysozyme (Brondz \& Brondz, 2011). Bile acids (in vivo) play the same role as ethylenediaminetetraacetic acid (EDTA) in rea gent glass (in vitro), and in this way, enable lysozyme to dissolve gram-negative bacteria (Brondz \& Brondz, 2011).

\subsubsection{Cholesterol as a Precursor to Bioactive Molecules}

In different organs, cholesterol is a precursor to some bioactive molecules. It is the precursor molecule for the synthesis of vitamin D and steroid hormones such as cortisol and aldosterone and sex hormones such as progesterone, estrogen, testosterone, and their derivatives (Hanukodlu, 1992; Payne \& Hales, 2004; Boyd \& Simpson, 1968; Dong \& Hardy, 2004). The enzymes and pathways involved in the biosynthesis of active steroid hormones from cholesterol in the gonads, adrenal glands, and placenta have been described (Payne \& Hales, 2004). From an organism's total available cholesterol (i.e., endogenous and exogenous), only a small fraction is transformed into hormones. The hormones derived from cholesterol promote glucose synthesis, suppress inflammatory reactions (i.e., glucocorticoids), regulate ion balances (i.e., mineralocorticoids), promote female sex characteristics (i.e., estrogen), are active during pregnancy (i.e., progestin), and promote male sex characteristics (i.e., androgen). One steroid hormone in the glucocorticoid class is cortisol, which is synthesized from cholesterol (see Figure 2 for the cortisol molecule), which is synthesized by the zona fasciculata of the cortex of the adrenal gland (Hu, Zhang, Shen, \& Azhar, 2010). 


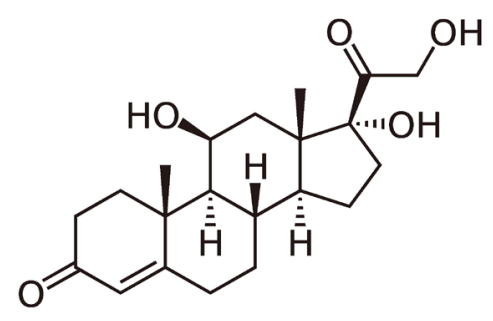

Figure 2. The cortisol molecule.

These bioactive molecules are clearly important to human health and fecundity. A society with normal levels of these substances have positive demographic growth, whereas a society with low levels of these substances have demographic stagnation or negative growth. Cholesterol also plays an important role as a signaling agent: "Cholesterol is also implicated in cell signaling processes, assisting in the formation of lipid rafts in the plasma membrane, which brings receptor proteins in close proximity with high concentrations of second messenger molecules" (Incardona \& Eaton, 2000). The cholesterol molecule is involved in many other biological activities either directly or through metabolic transformation to other bioactive molecules.

\subsubsection{Medical Implications}

High cholesterol levels are associated with atherosclerosis and an increased risk of myocardial infarction, stroke, peripheral artery disease, and many other illnesses. In this context, it is referred to as "bad cholesterol" (i.e., low-density lipoprotein) or "good cholesterol" (i.e., high-density lipoprotein) (Brunzell, Davidson, Furberg, Goldberg, Howard, Stein, \& Witztum, 2008). The consumption of pork, which is high in cholesterol can provoke illnesses, but not in isolation. In 1999, Forman discredited evidence showing that the consumption of red meat causes coronary heart disease (CHD) and cancer, which implicated beef, lamb, venison (including elk), and many other sources of protein as harmful.

Humanoid apes and humans were originally vegetarian; however, humans are limited by a strict vegetarian diet because it lacks de novo synthesis of several essential amino acids and vitamins. From their evolutionary origins, humanoid apes and humans added protein-containing foods, including beans, larva, insects, worms, rodents, and carrion, to their vegetarian diets. Gorillas and chimpanzees are anthropophagi, hunting small monkeys, including the Nilgiri langur, black-footed gray langurs, and cherry-crowned mangabeys. Although processed meats (e.g., cooked, steaked, stuffed, salted) are more easily digested, they also contain many harmful ingredients (e.g., preservatives, flavorings, antioxidants, conservatives). Roasted and fried meats are most harmful, though they are also preferred because of their flavor. Animal husbandry also includes the use of antibiotics, insecticides, and (often) hormones. There is no doubt about the harms of these additives to human health. Pigs have the greatest exposure to these chemicals, and the concentration of these substances in porcine is therefore high. Porcine is an easily degraded meat (with and without bacterial presence), 
and at elevated temperatures, all of these additives can be converted to cancerogenic substances. Porcine can be highly contaminated with bacteria. Though nitrates were previously used to preserve meat, nitrites are currently used more commonly to prevent the growth of pathogens such as Clostridium botulinum. Nitrates are also more toxic than nitrites, both of which can be precursors to the synthesis of cancerogenic nitro-substances. The other precursors for the synthesis of cancerogenic nitro-substances are amines (of a biogenic nature), amino acids, and phospholipids. The reactions of nitrites and nitrates to creatine and creatinine in acidic liquid to create nitrosamines has been studied in vitro (Velíšek, Davídek, \& Klein, 1974; Archer, Clark, Thilly, \& Tannenbaum, 1971; Mirvish, 1975; Hotchkiss, 1988). Nitrosamine and the products of nitrosation have high cancerogenic potential. The carcinogenicity of some nitrosation products has also been described (Wogan, Paglialunga, Archer, \& Tannenbaum, 1975; Toyama, Shimizu, Suzuki, Miyakoshi, \& Yoshioka, 2006). The significance in the process of nitrosation of amines has enteric microflora, a process that can occur in a neutral or even basic environment. Microflora in the oral cavity, gut and urine bladder can reduce nitrites by catalysis and catalyzed nitrosation through activation by bacterial ferments. Microsomal enzymes are evolutionary tools for deactivating harmful, toxic substances that appear in the bodies of higher animals, acting by oxidation. However, most toxins, pesticides, insecticides, and synthetic toxins are more toxic in their oxidized forms (Krieger, 2010). For example, malathion is less toxic than the oxidized molecule malaoxon, and diazoxon is more toxic than non-oxidized diazinon (Brondz, 2015). Figure 3 shows diazinon and diazoxon molecules. Toxins, pesticides, and insecticides are concentrated in fatty tissue deposits.

Some organophosphates, such as malathion, malaoxon, diazinon, and diazoxon, are endocrine disruptors that greatly influence sexual performance, fecundity, and cognition. Synthetic hormones are used broadly in animal husbandry, the residuals of which are present in meat, especially swine white hypodermal fat. The influence of these residuals on human health is so apparent that no discussion is necessary. Some aspects of the potential influences of organophosphates on cognitive ability and endocrine disruption have been described elsewhere (Brondz, 2015).

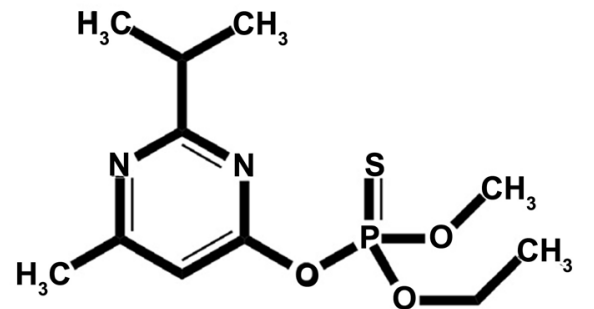

Diazinon

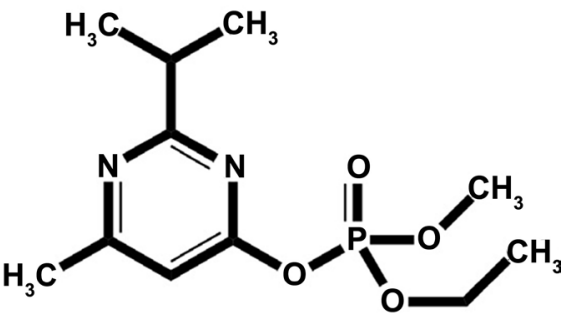

Diazoxon

Figure 3. The diazinon (left) and diazoxon (right). 


\section{How Pork Can Influence Human Sexual Ability and Fecundity}

Some but not all of the negative influences on human health have been described above; however, Brondz (Brondz, 2018) presented the following hypothesis regarding the prohibition against pork consumption. It is possible that ancient Egyptian priests were aware of some of the negative influences of pork consumption, even though they could not have predicted the use of harmful chemicals in food processing or the use of pesticides, insecticides, and hormones in livestock. The residues of these toxic contaminants are present in porcine and all meats consumed today. Many of these substances influence human sexual ability and fecundity because, like all organophosphate insecticides (Brondz, 2015), they are endocrine disruptors that influence both individuals' sexuality and demography.

\section{Positive and Negative Demographic Consequences}

Moses, by order of the Lord of Israel, freed the Jews from Egyptian slavery. The Jews lived for 40 years in Sinai with a restricted food supply. Food and water supplies should remain balanced within any population, and Moses was knowledgeable about different fields of science, as both the adopted son of the Pharaoh and a prince who studied at temples and was educated by high priests. He also understood the influence of pork on medical health and sexual ability. The lifestyle and maturation of pigs has been quoted as describing in (Brondz, 2018). Pigs have a short life cycle, reaching maturity at 3 to 12 months of age, entering estrous every 18 to 24 days, and having a gestational period of only 112 to 120 days. Thus, they have the highest concentration of sexual hormones among all domestic animals, especially in their fatty tissues (unpublished and incomplete results from our laboratory). Pork consumption may therefore influence fecundity and sexual patterns. We compared three nations with ancient histories and different attitudes toward pork prohibition. It is well known that Hindus do not consume cattle meat, even though they have no prohibition against pork; the Chinese keep pigs as primary domestic animals and a main protein source, while Jews have a prohibition against porcine. These three cultures are all ancient and, relative to their historic origins, have a similar number of individuals at the start in approximately 5.000 years B. C. These similarities and differences make it interesting to study these nations' demographics. Each of these nations has suffered a significant loss of population during their history. Hindus were starved under the influence of the East India Company, the English company formed in 1600. The Great Bengal Famine of 1770 caused the deaths from starvation of about 10 million (Sen, 1981), or a third of the population in the affected region (Jonsson, 2013; Davis, 2001). Plague has also frequently decreased this population. The Chinese also sustained heavy losses during WWII and the Liberation War (1931-1949), when more than 35 million were killed. Published accounts include only the period from 1937-1945, but Japan's invasion of the continent 
began earlier, in 1931 in China and in 1927 in Mongolia. Deaths from military activities only and crimes against humanity during the period from 1937 to 1945 totaled 8.2 million. The total number of deaths during the same period was 20 million, with up to $4 \%$ of the population being murdered (Todd, 2017). China's population has often been diminished by plague. The Hindus and Chinese have large populations, while the Jews are sparsely in number. It could be argued that throughout history, Jews have been severely prosecuted. In the seventh century B. C., half of the nation was deported by Assyrians, subsequently vanishing, and during the first century $\mathrm{AD}$, nearly half of the nation was killed by the Romans. A third of the Jewish nation was murdered by Nazi prosecution during 19331945 in Germany and on all occupied territories (Gilbert, 2001), 6 million Jews were murdered during 1941-1945 alone across German-occupied Europe (Gilbert, 2001; The Holocaust); assassinations and terrorist actions targeting Jews continue today (Terence, 1976; McGreal, 2006; Sweis, 2018; Greenblatt, 2018; Koehler, 2019). Was their nutritional style (i.e., prohibition) a cause of their demographic differences, or did criminal activity (i.e., prosecution) cause the Jews' demographic circumstances? Regardless, this discussion would be incomplete without comparing the Jewish and Arab nations. Jews and Arabs follow the same prohibition as Semites and the sons of Abraham: "Ismael and Isaac are sons of Abraham. Abraham is offspring of Eber. Eber is offspring of Sem. Offspring of Ismael and Isaac are Semites" (Brondz, 2020). If this version is accepted, then one people gave rise to these two nations, which now number about 15 million Jews and 300 million Arabs. Throughout history, Arabs have also been diminished by repeated mass murders, severe famines, and frequent outbreaks of cholera and plague. Despite their theological disputes, Judaism and Islam share many customs. Some specific lifestyle patterns may aggravate the negative influences of prohibition, whereas others enhance its positive influence. That Jews adopted the European lifestyle of monogamy, despite the historic acceptance of four or more wives (Brondz, 2020; Holy Bible, King James Version, 2010; The Torah, 2010), while polygamy has been institutionalized in Islam (The Koran, 1900), is an important difference. Muslim men have the opportunity for uninterrupted, productive sexual activity, while the sexual activity of monogamous Jews pauses while the wife is menstruating. Another difference is that Islam forbids female prostitution by Muslim women, though brothels are common in Muslim countries, where they are populated by Hindus, Chinese, Jews, Christian Europeans, and even Christian Arabs and Pagans. As such, Muslim women of reproductive age are not removed from the demographic equation. Anther restriction in Islam is the prohibition on abortion, which significantly reduces, if not entirely prevents, non-productive reproduction among Muslims, and Arabs as part of community. Only a small number of secular Islamic women seek an abortion, in contrast to Jews. In contrast to modern Judaism, Islam is remarkably like Yahvism (the worship of Yahweh (Jehovah)) (Moses, 1903) in the time of Moses. The marriage of Islamic women to non-Muslim men is rare, in con- 
trast to the marriage of Islamic men to non-Muslim women, who usually convert to Islam. Many Jews enter secular mixed marriages, which does not lead to a change in religious status. During the last several decades, when the Soviet Union and Yugoslavia were dissolved, many women entered prostitution in the West and Muslim lands. From a practical perspective, Islam is a healthier religion than Judaism or Christianity, as reflected by its Reconquista campaigns of the West generally, and in Europe in particular. A negative custom in local Islamic communities is female circumcision, although this custom is more common in central and south Africa, where the Arab population is limited. In sum, the differences described herein, and some that were beyond the scope of this paper, all play a significant role in the different demographic situations among Jews and Arabs. Lifestyles connected to prohibition can have both positive and negative influences on these groups' demographics.

\section{Conclusion}

The question of the positive and negative consequences of the prohibition against pork consumption is a longstanding one that requires a more thorough and careful investigation. It is quite interesting to investigate hormonal concentrations in pork and to study its consumption versus prohibition in relation to demography. It is also interesting to investigate the influences of the politically, religiously, and xenophobically motivated mass murder (which without of doubt had an influence) on demography of the people of these nations.

\section{Conflicts of Interest}

The author declares no conflicts of interest regarding the publication of this paper.

\section{References}

Archer, M. C., Clark, S. D., Thilly, J. E., \& Tannenbaum, S. R. (1971). Environmental Nitroso Compounds: Reaction of Nitrite with Creatine and Creatinine. Science, 174, $1341-$ 1343. https://doi.org/10.1126/science.174.4016.1341

Boyd, G. S., \& Simpson, E. R. (1968). Studies on the Conversion of Cholesterol to Pregnenolone in Bovine Adrenal Mitochondria. In K. W. McKern (Ed.), Functions of Adrenal Cortex (Vol. 1, pp. 49-76). New York: Appleton-Century-Crofts.

Bragagnolo, N., \& Rodriguez-Amaya, D. B. (2002). Simultaneous Determination of Total Lipid, Cholesterol and Fatty Acids in Meat and Backfat of Sucling and Adult Pigs. Food Chemistry, Analytical, Nutritional and Clinical Methods Section, 79, 255-260. https://doi.org/10.1016/S0308-8146(02)00136-X

Brondz, I. (2002). Review, Development of Fatty Acid Analysis by High-Performance Liquid Chromatography, Gas Chromatography, and Related Techniques. Analytica Chimica Acta, 465, 1-37. https://doi.org/10.1016/S0003-2670(01)01467-2

Brondz, I. (2005). Lipids, Fatty Acids. In P. J. Worsfold, A. Townshend, \& C. F. Poole (Eds.), Encyclopedia of Analytical Sciences (2nd ed., Vol. 5, pp. 76-88). Amsterdam: Elsevier. https://doi.org/10.1016/B0-12-369397-7/00310-1 http://www.worldcat.org/title/lipids-fatty-acids/oclc/4934332051\&referer=brief_results 
Brondz, I. (2015). High-Performance Liquid Chromatograph (HPLC) Equipped with a Neurophysiological Detector (NPD) as a Tool for Studying Olfactory System Intoxication by the Organophosphate (OP) Pesticide Diazinon and the Influence of OP Pesticides on Reproduction. International Journal of Analytical Mass Spectrometry and Chromatography, 3, 14-24. https://doi.org/10.4236/ijamsc.2015.31002

Brondz, I. (2016). Fatty Acids. In Reference Module in Chemistry, Molecular Sciences and Chemical Engineering. http://dx.doi.org/10.1016/B978-0-12-409547-2.13780-1 https://www.sciencedirect.com/science/article/pii/B9780124095472137801?via\%3Dihub

Brondz, I. (2016). Lipids, Fatty Acids. In J. Reedijk (Ed.), Elsevier Reference Module in Chemistry, Molecular Sciences and Chemical Engineering. Waltham, MA: Elsevier. https://www.researchgate.net/publication/313852715_LIPIDS_Fatty_Acids

Brondz, I. (2018). Why Judaism and Islam Prohibit Eating Pork and Consuming Blood as a Food? Voice of the Publisher, 4, 22-31. https://doi.org/10.4236/vp.2018.42003

Brondz, I. (2020). Circumcision: Part II, Is Abraham the Patriarch Only of Jews? Voice of the Publisher, 6, 18-30. https://doi.org/10.4236/vp.2020.62003

Brondz, I., \& Aslanova, T. (2019). Circumcision: History, Scope, and Aim: Part I. Voice of the Publisher, 5, 77-87. https://doi.org/10.4236/vp.2019.54006

Brondz, I., \& Brondz, A. (2011). Suppression of Immunity by Some Pesticides, Xenobiotics, and Industrial Chemicals. In Vitro Model. Journal of Biophysical Chemistry, 2, 226-232. https://doi.org/10.4236/jbpc.2011.23028

Brunzell, J. D., Davidson, M., Furberg, C. D., Goldberg, R. B., Howard, B. V., Stein, J. H., \& Witztum, J. L. (2008). Lipoprotein Management in Patients with Cardiometabolic Risk: Consensus Statement from the American Diabetes Association and the American College of Cardiology Foundation. Diabetes Care, 31, 811-822. https://doi.org/10.2337/dc08-9018

Davis, M. (2001). Late Victorian Holocausts: El Niño Famines and the Making of the Third World. London, New York: Verso.

Dong, Q., \& Hardy, M. P. (2004). Leydig Cell Function in Man. In S. J. Winters (Ed.), Male Hypogonadism. Contemporary Endocrinology (pp. 23-43). Totowa, NJ: Humana Press. https://doi.org/10.1007/978-1-59259-727-7_2

Fouilloux, C., Ringler, E., \& Rojas, B. (2019). Cannibalism. Current Biology, $29,4$. https://doi.org/10.1016/j.cub.2019.09.068

Gilbert, M. (2001). Final Solution. In I. Dear, \& R. D. Foot (Eds.), The Oxford Companion to World War II (pp. 285-292). Oxford: Oxford University Press.

Greenblatt, J. A. (2018). When Hate Goes Mainstream. The New York Times (October $28,2018)$.

https://www.nytimes.com/2018/10/28/opinion/synagogue-shooting-pittsburgh-anti-de famation-league.html

Hanukodlu, I. (1992). Steroidogenic Enzymes: Structure, Function, and Role in Regulation of Steroid Hormone Biosynthesis. The Journal of Steroid Biochemistry and Molecular Biology, 43, 779-804. https://doi.org/10.1016/0960-0760(92)90307-5

Hjelmgaard, K. (2017). Russian "Cannibal Couple” Confess to Eating 30 People, Sold "Meat Pieces" at Army Base, Police Say. USA Today. https://www.usatoday.com/story/news/world/2017/09/27/russian-cannibal-couple-conf ess-eating-30-people-sold-meat-pieces-army-base-police-say/707255001

Holy Bible, King James Version (2010). Zondervan. The Gideons International. The British Isles, Lutterworth, England.

Hotchkiss, J. H. (1988). A Review of Current Literature on N-Nitroso Compounds in 
Foods. Advances in Food Research, 31, 53-115.

https://doi.org/10.1016/S0065-2628(08)60166-4

Hu, J., Zhang, Z., Shen, W.-J., \& Azhar, S. (2010). Cellular Cholesterol Delivery, Intracellular Processing and Utilization for Biosynthesis of Steroid Hormones. Nutrition \& Metabolism, 7, 47. https://doi.org/10.1186/1743-7075-7-47

Incardona, J. P., \& Eaton, S. (2000). Cholesterol in Signal Transduction. Current Opinion in Cell Biology, 12, 193-203. https://doi.org/10.1016/S0955-0674(99)00076-9

Jonsson, F. A. (2013). Enlightenment's Frontier, the Scottish High Lands and the Origins of Environmentalism. New Haven, CT, London: Yale University Press.

Kasprzyk, A., Tyra, M., \& Babicz, M. (2015). Fatty Acid Profile of Pork from a Local and a Commercial Breed. Archives Animal Breeding, 58, 379-385.

https://doi.org/10.5194/aab-58-379-2015

http://www.arch-anim-breed.net/58/379/2015

Koehler, D. (2019). The Halle, Germany, Synagogue Attack and the Evolution of the Far-Right Terror Threat. CTC Sentinel, 12, 14.

https://ctc.usma.edu/halle-germany-synagogue-attack-evolution-far-right-terror-threat https://ctc.usma.edu/wp-content/uploads/2020/02/CTC-SENTINEL-112019.pdf

Krieger, R. (2010). The Handbook of Pesticide Toxicology (3rd ed.). Cambridge, MA: Academic Press, Elsevier Inc.

List of Incidents of Cannibalism. https://en.wikipedia.org/wiki/List_of_incidents_of_cannibalism

Maraschiello, C., Díaz, I., \& Regueiro, J. A. G. (1996). Determination of Cholesterol in Fat and Muscle of Pig by HPLC and Capillary Gas Chromatography with Solvent Venting Injection. Journal of High Resolution Chromatography, 19, 165-168. https://doi.org/10.1002/jhrc.1240190309

McGreal, C. (2006). Hamas Drops Call for Destruction of Israel from Manifesto. The Guardian. https://www.theguardian.com/world/2006/jan/12/israel

Mirvish, S. S. (1975). Formation of N-Nitroso Compounds: Chemistry, Kinetics, and in Vivo Occurrence. Toxicology and Applied Pharmacology, 31, 325-351. https://doi.org/10.1016/0041-008X(75)90255-0

Moses, A. E. A. (1903). Yahvism: And Other Discourses. University of California Libraries, ASIN: B0088HR4UQ. (This Book Can Be Found Online in the HathiTrust Digital Library) http://www.hathitrust.org

Payne, A. H., \& Hales, D. B. (2004). Overview of Steroidogenic Enzymes in the Pathway from Cholesterol to Active Steroid Hormones. Endocrine Reviews, 25, 947-970. https://doi.org/10.1210/er.2003-0030

Sen, A. (1981). Poverty and Famines: An Essay on Entitlement and Deprivation. Oxford, New York: Clarendon Press, Oxford University Press. https://archive.org/details/povertyfamineses0000sena

Stewart, W. (2017). Meat and Greet Russian Cannibal Couple "Killed Female Pal in Vodka Fuelled Jealous Rage-And Likely Sold Her Body Parts in a MEAT PIE. The Sun. https://www.thesun.co.uk/news/4574755/russian-cannibal-couple-killed-pal-vodka-rage

Sweis, R. (2018). Iran Pledges to Destroy Israel within 25 Years as Tensions Rise. The Telegraph.

https://www.telegraph.co.uk/news/2018/04/22/iran-pledges-destroy-israel-within-25-y ears-tensions-rise

Terence, S. (1976). Hostages Freed as Israelis Raid Uganda Airport; Commandos in 3 Planes Rescue 105-Casualties Unknown Israelis Raid Uganda Airport and Free Hijack- 
ers' Hostages. The New York Times.

https://www.nytimes.com/1976/07/04/archives/hostages-freed-as-israelis-raid-ugandaairport-commandos-in-3.html

The Holocaust, from Wikipedia, the Free Encyclopedia. https://en.wikipedia.org/wiki/The_Holocaust\#CITEREFGilbert2001

The Koran, The Holy Book of Islam with Introduction and Notes, Translated by Palmer, E. H. (Was First Published in 1900), This Edition First Published in 2017 by Watkins, an Imprint of Watkins Media Limited, London.

The Torah (2010). London: Kuperard.

Todd, M. (2017). China Lost 14 Million People in World War II. Why Is This Forgotten? Pacific Standard. (Original Published by MICHAEL TODD September 2013) https://psmag.com/news/china-lost-14-million-people-world-war-ii-forgotten-66482

Toyama, Y., Shimizu, H., Suzuki, Y., Miyakoshi, Y., \& Yoshioka, H. (2006). Genotoxic Effects of N-Nitrosoketamine and Ketamine as Assessed by in Vitro Micronucleus Test in Chinese Hamster Lung Fibroblast Cell Line. Environmental Health and Preventive Medicine, 11, 120-127. https://doi.org/10.1265/ehpm.11.120

Velíšek, J., Davídek, J., \& Klein, S. (1974). Polarographic Determination of the Nitrosation Products of Creatine and Creatinine. Zeitschrift für Lebensmittel-Untersuchung und Forschung, 155, 203-208. https://doi.org/10.1007/BF01089746

Wogan, G. N., Paglialunga, S., Archer, M. C., \& Tannenbaum, S. R. (1975). Carcinogenicity of Nitrosation Products of Ephedrine, Sarcosine, Folic Acid, and Creatinine. Cancer Research, 35, 1981-9814. 